Trinity College

Trinity College Digital Repository

Faculty Scholarship

6-2006

Potential factors influencing nest defense in diurnal North American raptors

Joan L. Morrison

Trinity College, joan.morrison@trincoll.edu

Madeline Terry

Patricia L. Kennedy

Follow this and additional works at: https://digitalrepository.trincoll.edu/facpub

Part of the Biology Commons 


\title{
POTENTIAL FACTORS INFLUENCING NEST DEFENSE IN DIURNAL NORTH AMERICAN RAPTORS
}

\author{
JOAN L. MORRISON 1 \\ Department of Biology, Colorado State University, Fort Collins, CO 80523 U.S.A.
}

\author{
Madeline Terry ${ }^{2}$ ANd Patricia L. KenNedy 3 \\ Department of Fishery and Wildlife Biology, Colorado State University, Fort Collins, CO 80523 U.S.A.
}

\begin{abstract}
Nesting habitat, predator type, and level of reproductive effort influence nest defense behaviors in many bird species, yet no study has examined these or other possible factors influencing nest defense in a cross-species comparison for raptors. Using data from the literature, we grouped the nest defense behaviors of 19 diurnal North American raptors into four categories based on a gradient of aggressiveness. For each species, we identified the cover types where nesting occurred, accessibility of nest location, assessed two indices of reproductive effort, and examined associations between these factors and nest-defense behavior. We also we examined responses by raptor species to different predator types including diurnal avian, nocturnal avian, mammalian (not human), and human. Most raptor species with high reproductive effort exhibited very aggressive nest defense. Most raptor species nesting in open cover types and species with accessible nests showed aggressive nest defense. While many raptors react aggressively toward diurnal and nocturnal avian predators, they exhibit less aggressive defense against potential human predators. Results from this study suggest that a variety of factors may influence nestdefense strategies used by diurnal raptors. However, more work is needed on the relative influence of these factors (including predation risk) and variation in raptor nest defense strategies before general patterns can be elucidated.
\end{abstract}

KEY WORDS: Nest defense; breeding behavior; reproductive effort; aggressive behavior; predation risk.

\section{FACTORES POTENCIALES QUE AFECTAN LA DEFENSA DEL NIDO EN AVES RAPACES DIURNAS DE AMÉRICA DEL NORTE}

RESUMEN.-El hábitat de nidificación, el tipo de depredador y el nivel del esfuerzo reproductivo influencian los comportamientos de defensa del nido en muchas especies de aves. Sin embargo, no hay estudios que hayan examinado estos $u$ otros posibles factores que influencian la defensa del nido en comparaciones entre especies de rapaces. Usando datos de la literatura, agrupamos los comportamientos de defensa del nido de 19 rapaces diurnas de América del Norte en cuatro categorías basadas en el nivel de agresividad. Para cada especie, identificamos los tipos de cobertura donde se localizaron los nidos y su accesibilidad, evaluamos dos índices de esfuerzo reproductivo y examinamos las asociaciones entre estos factores y los comportamientos de defensa del nido. También examinamos las respuestas de cada especie de ave rapaz a los diferentes tipos de depredadores, incluyendo aves diurnas, aves nocturnas, mamíferos (no humanos) y humanos. La mayoría de las especies de rapaces con un alto esfuerzo reproductivo exhibieron defensas del nido muy agresivas. La mayoría de las especies de rapaces que nidifican en tipos de cobertura abiertos y las especies con nidos accesibles mostraron defensas del nido agresivas. Aunque muchas especies de rapaces reaccionan agresivamente contra las aves depredadoras diurnas y nocturnas, al mismo tiempo muestran defensas menos agresivas contra potenciales depredadores humanos. Los resultados de este estudio sugieren que una variedad de factores pueden influenciar las estrategias de defensa del nido usadas por las rapaces diurnas. Sin embargo, se requiere trabajo adicional para entender la influencia relativa de estos

1 Present address: Department of Biology, Trinity College, Hartford, CT 06106 U.S.A.; email: joan.morrison@trincoll.edu

2 Present address: Science Applications International Corporation, 8100 Shaffer Parkway, Suite 100, Littleton, CO 80127 U.S.A.

${ }^{3}$ Present address: Eastern Oregon Agricultural Research Station, Oregon State University, P.O. Box E, Union, OR 97883 U.S.A. 
factores (incluyendo el riesgo de depredación) y la variación en las estrategias de defensa de las rapaces antes de poder dilucidar patrones generales.

[Traducción del equipo editorial]

Predation on eggs and nestlings is a primary cause of reproductive failure among birds, thus many species exhibit defense behavior when predators approach the nest. Nest defense behavior may reflect an optimization of costs and benefits to the parent birds' fitness in relation to current versus future reproduction (Barash 1975, Montgomerie and Weatherhead 1988), yet large variation in the extent of nest defense exists among and within species. Factors that may influence the type and degree of nest defense include nest type and nesting habitat or site (Curio et al. 1985, Albrecht and Klvana 2004), food abundance (Tolonen and Korpimäki 1995), predator type including humans (Brunton 1990, Winkler 1992), offspring value (Grieg-Smith 1980, Olendorf and Robinson 2000), and risk factors to either the young or defending parent (Regelmann and Curio 1983, Krüger 2002).

Nest defense by birds of prey may differ from that of other birds because raptors can potentially attack and injure would-be predators. In addition, raptor young can be considered to have relatively high value because many species reproduce, on average, once annually or less and have relatively few young, and for some species, a scarcity of safe nest sites may limit breeding density and success (Newton 1979, Village 1983). Many raptors are also highly sensitive to human disturbance, possibly because of continued persecution in some areas (Newton 1979). Thus, as a group, raptors may be expected to exhibit relatively aggressive nest defense.

Numerous studies of avian nest defense have focused on single species and factors potentially influencing the type and extent of defense behaviors (reviewed in Redondo 1989). By seeking repeated patterns throughout a broad taxonomic group, comparative studies of behavior can lend insight into evolutionary and ecological factors potentially underlying interspecific variation (for examples see Röell and Bossema 1982, Larsen et al. 1996, Meilvang et al. 1997, Gunness and Weatherhead 2002). We used a comparative approach (Harvey and Pagel 1991) to explore patterns of nest defense exhibited by diurnal North American raptors and to assess factors that might influence these behaviors. Our underlying hypotheses were: (1) parental defense decisions are influenced by risk to the developing young or risk to the defending parent, and (2) more aggressive defense would be exhibited by species for which young are more vulnerable or of greater value.

\section{METHODS}

We defined a raptor's nesting period as the time during which adults are tending an occupied nest (includes egglaying, incubation, and nestling stages). We identified four categories of behavior (sensu Hudson and Newborn 1990) potentially exhibited by a raptor when a predator approaches the nest: (1) no defense, bird may fly away (no defense), (2) circles or calls when predator approaches (passive response), (3) dives at or chases predator, but makes no physical contact (somewhat aggressive), and (4) physically attacks predator (very aggressive). Using information from journal articles, review papers, and books, we recorded accounts of nest defense for diurnal raptors in North America and assigned each account to one of the above four categories based on behavioral descriptions. We defined "account" as any mention of nest defense behavior by the author(s). If more than one defense behavior was noted for the same individual during the same observation, we recorded it as one account and classified it according to the most aggressive behavior noted. If the author(s) reported defense behavior exhibited by another individual or by the same individual on another day or against a different predator, we recorded those observations as separate accounts of nest defense. For example, if a raptor called, chased, or attacked a predator during three separate observations, we gave that species one account of nest defense for call/ circle, one account for dive/chase, and one account for attack.

After compiling all accounts for each raptor species in the dataset, we included only those species having four or more accounts of nest defense in subsequent analyses. We assigned each species to one overall defense category (no defense, passive response, somewhat aggressive, or very aggressive) based on the category with the highest frequency of accounts for that species recorded from all data sources; we assumed this category represented the "typical" defense behavior of that species. If more than one category had the same number of accounts, we assigned the species to the more aggressive category.

A priori, we identified four factors that may influence nest defense of raptors. First, we examined reproductive effort, predicting that raptors with high reproductive effort throughout the nesting period defend nests more aggressively than species with low reproductive effort throughout the nesting period (Redondo 1989). Second, we examined the cover types where nesting occurred, predicting that raptors nesting in open cover types exhibit less aggressive or no defense because such behaviors might be overtly conspicuous to visually-oriented predators leading to high rates of nest discovery and loss (Carillo and Aparicio 2001, Bures and Pavel 2003). Third, we examined nest accessibility, predicting that nests easily 
accessed by predators (ground and tree nests) are defended more aggressively than nests that are more difficult to access (cliff and cavity nests), because accessible nests incur higher predation rates (e.g., Martin 1995, Wesolowski and Tomialojć 2005). Finally, we examined responses by raptor species to different predator types, predicting that raptors exhibit less aggressive nest defense toward humans than toward other mammalian or avian predators because raptors may recognize humans either as non-predators or as large predators against which the response risk to themselves is high (Knight et al. 1989, Galeotti et al. 2000).

We developed two indices of reproductive effort. One represented effort during the early part of the nesting period (egg-laying stage) and one represented effort in the latter part (incubation and nestling stages). Early reproductive effort was the investment required to produce a clutch calculated as average egg volume times average clutch size. We calculated egg volume as $\mathrm{K}_{\mathrm{v}} \times \mathrm{LB}^{2}$, where $\mathrm{L}=$ length and $\mathrm{B}=$ breadth of the egg, respectively (in $\mathrm{mm}$ ), and $\mathrm{K}_{\mathrm{v}}=0.0005$ (for oval eggs; Hoyt 1979). We defined reproductive effort in the latter part of the nesting period as time spent incubating eggs and raising nestlings. We calculated this index as the sum of the mean incubation period and the mean nestling period (both in days) for each species. Because both measures were correlated with female body mass, we used the residuals of the regression analyses of early and late reproductive effort, respectively, on log female body mass as the indices in subsequent analyses. We calculated both indices for each species and then ranked each index separately using a ranking function in Microsoft Excel ${ }^{(C)}$ (Microsoft Corp. 2000, Redmond, WA U.S.A). We classified species for which the residuals were $\leq 0$ as having low reproductive effort and species for which the residuals were $>0$ as having high reproductive effort, for both the early and latter part of the nesting period. We obtained information on clutch size, length of incubation and nestling periods, and female body mass from species accounts in the Birds of North America series (Poole and Gill 2002).

We classified nesting cover type for each species as either open (including grasslands, tundra, deserts, and areas with scattered trees or shelterbelts) or closed (including all forested communities containing deciduous, coniferous, or mixed tree species with a predominately closed canopy cover). We defined nests for each species as either accessible (ground and tree nests) or inaccessible (cliff and cavity nests). For early and late reproductive effort, nesting cover type, and nest accessibility, we examined proportions of raptor species in our dataset that have either no defense, passive response, somewhat aggressive, or very aggressive nest defense.

We examined responses by raptors to a suite of potential predators. For each account of defensive behavior, when possible, we identified the predator against which the behavior was directed as (1) diurnal avian (e.g., crows [Corvus spp.]), (2) nocturnal avian (e.g, owls), (3) mammalian (not human, e.g., squirrels), and (4) human. Then we classified each account for which the predator could be identified into one of the aforementioned four nest defense categories.

Although our initial investigations were conducted at the species level, we recognized that evolution of behavior may have a strong historical component and that data sampled across several closely-related species may not be independent (Harvey and Pagel 1991, Freckleton 2000). Therefore, to help control for phylogenetic constraints, we further investigated patterns in nest defense at the genus level, for early and late reproductive effort, nesting cover type and nest accessibility, for all raptors in our dataset. Because of uncertainty in phylogenetic relationships within Falconiformes (e.g., Griffiths et al. 2004, Kruckenhauser et al. 2004), we also conducted a qualitative examination of possible phylogenetic constraints in our evaluation of raptor nest defense by mapping these behavior patterns on available phylogenies for birds. of prey (Griffiths 1999, Riesing et al. 2003).

\section{RESULTS}

There were 19 species of diurnal North American raptors for which we found at least four accounts of nest defense (Table 1). For some, including Crested Caracara (Caracara cheriway), Bald Eagle (Haliaeetus leucocephalus), Golden Eagle (Aquila chrysaetos), and White-tailed Hawk (Buteo albicaudatus), we recorded accounts in which the raptor simply left the nest area upon approach of a predator. However, we classified these raptors as having "passive response" nest defense because there were accounts describing calling and circling behavior against a predator for all four species (Table 1). We classified all other species as having either somewhat aggressive or very aggressive nest defense (Table 1).

Reproductive Effort. Most raptor species with high reproductive effort throughout the nesting period (4 of 5 species) exhibited very aggressive (attack) nest defense (Table 1). At the genus level this proportion rises to $100 \%$. Most accounts for raptor species with low reproductive effort throughout the nesting period (4 of 5 species) reported diving and chasing, but few attack behaviors; this pattern is also apparent at the genus level. Accounts for species with high reproductive effort only during the early nesting period (egg-laying), for example Prairie Falcons (Falco mexicanus), Cooper's Hawks (Accipiter cooperii), and Osprey (Pandion haliaetus; Table 1), indicated very aggressive nest defense. In contrast, most species with high reproductive effort during only the latter part of the reproductive period (incubation and nestling stages, $N=6$ ) exhibited only passive response nest defense; the same pattern occurred at the -genus level. This group included the larger species such as the two eagles, Crested Caracaras, and White-tailed Hawks. The smaller-bodied Merlin (Falco columbarius), also in this group, exhibited very aggressive nest defense, however. 
Table 1. Information on factors potentially influencing nest defense of diurnal North American raptors for which we found at least four accounts of nest defense in the literature ( $N=19$ species). Categories of nest defense are: (1) no defense, bird may fly away (no defense), (2) circles or calls when predator approaches (passive response), (3) dives at or chases predator, but makes no physical contact (somewhat aggressive) and (4) physically attacks predator (very aggressive). Reproductive effort: $\mathrm{H}=$ high, $\mathrm{L}=$ low. Nesting cover type: $\mathrm{O}=$ open, $\mathrm{C}=$ closed (see text for further descriptions). Nest accessibility: $\mathrm{A}=$ accessible (ground or tree), $\mathrm{I}=$ inaccessible (cliff or cavity).

\begin{tabular}{|c|c|c|c|c|c|c|c|c|c|c|c|}
\hline \multirow[b]{2}{*}{ SPECIES } & \multirow{2}{*}{$\begin{array}{c}\text { Nest } \\
\text { DEFENSE } \\
\text { CATEGORY }\end{array}$} & \multirow{2}{*}{$\begin{array}{c}\text { MEAN } \\
\text { FEMALE } \\
\text { MASS (g) }\end{array}$} & \multirow{2}{*}{$\begin{array}{l}\text { Avg. Clutch } \\
\text { Size }\end{array}$} & \multirow{2}{*}{$\begin{array}{c}\text { MEAN } \\
\text { CluTCH } \\
\text { VOLUME } \\
(\mathrm{ml})\end{array}$} & \multirow{2}{*}{$\begin{array}{l}\text { MEAN } \\
\text { INCUB. } \\
\text { PERIOD } \\
\text { (days) }\end{array}$} & \multirow{2}{*}{$\begin{array}{c}\text { MeAN } \\
\text { NeStling } \\
\text { PERIOD } \\
\text { (days) }\end{array}$} & \multicolumn{2}{|c|}{ REPRODUCTIVE EFFORT } & \multirow{2}{*}{$\begin{array}{l}\text { Nesting } \\
\text { HABITAT }\end{array}$} & \multirow{2}{*}{$\begin{array}{c}\text { NeST SITE } \\
\text { ACCESSIBILITY }\end{array}$} & \multirow[b]{2}{*}{ SOURCES } \\
\hline & & & & & & & EARLY & LATE & & & \\
\hline $\begin{array}{l}\text { Osprey } \\
\quad \text { Pandion haliaetus }\end{array}$ & 3 & 1600 & 3.3 & 212.2 & 37 & 53 & $\mathrm{H}$ & $\mathrm{L}$ & $\mathrm{O}$ & $\bar{A}$ & $\begin{array}{l}30,35,46,48 \\
49,50,55,59\end{array}$ \\
\hline $\begin{array}{l}\text { Northern Harrier } \\
\text { Circus cyaneus }\end{array}$ & 3 & 513 & 4.4 & 135.8 & 32 & 36 & $\mathrm{~L}$ & $\mathrm{~L}$ & $\mathrm{O}$ & A & $6,15,39,52$ \\
\hline $\begin{array}{l}\text { Cooper's Hawk } \\
\text { Accipiter cooperii }\end{array}$ & 4 & 566 & 4.3 & 154.2 & 36 & 32 & $\mathrm{H}$ & $\mathrm{L}$ & C & A & $\begin{array}{l}6,7,14,28,56 \\
57\end{array}$ \\
\hline $\begin{array}{l}\text { Northern Goshawk } \\
\text { Accipiter gentilis }\end{array}$ & 4 & 1137 & 3.0 & 176.1 & 37 & 45 & $\mathrm{H}$ & $\mathrm{H}$ & $\mathrm{C}$ & $\mathrm{A}$ & $\begin{array}{l}17,28,45,65, \\
66\end{array}$ \\
\hline $\begin{array}{l}\text { Harris's Hawk } \\
\quad \text { Parabuteo unicinctus }\end{array}$ & 3 & 998 & 3.0 & 142.5 & 35 & 40 & $\mathrm{~L}$ & $\mathrm{~L}$ & $\mathrm{O}$ & A & $5,6,18,28$ \\
\hline $\begin{array}{l}\text { Broad-winged Hawk } \\
\text { Buteo platypterus }\end{array}$ & 3 & 437 & 2.5 & 95.0 & 31 & 40 & $\mathrm{~L}$ & $\mathbf{H}$ & C & A & $3,6,9,29,47$ \\
\hline $\begin{array}{l}\text { Red-shouldered Hawk } \\
\text { Buteo lineatus }\end{array}$ & 4 & 670 & 3.5 & 188.2 & 33 & 42 & $\mathrm{H}$ & $\mathrm{H}$ & C & A & $3,16,28,33,47$ \\
\hline $\begin{array}{l}\text { White-tailed Hawk } \\
\text { Buteo albicaudatus }\end{array}$ & 2 & 1022 & 2.3 & 146.8 & 31 & 50 & $\mathrm{~L}$ & $\mathrm{H}$ & $\mathrm{O}$ & A & $6,23,24,28,68$ \\
\hline $\begin{array}{l}\text { Swainson's Hawk } \\
\text { Buteo swainsoni }\end{array}$ & 3 & 1109 & 2.3 & 131.5 & 28 & 30 & $\mathrm{~L}$ & $\mathrm{~L}$ & $\mathrm{O}$ & A & $6,13,22,75$ \\
\hline $\begin{array}{l}\text { Red-tailed Hawk } \\
\text { Buteo jamaicensis }\end{array}$ & 3 & 1224 & 2.5 & 168.4 & 30 & 45 & $\mathrm{~L}$ & $\mathrm{~L}$ & $\mathrm{O}$ & A & $1,25,36,53$ \\
\hline $\begin{array}{l}\text { Ferruginous Hawk } \\
\text { Buteo regalis }\end{array}$ & 3 & 1776 & 3.7 & 259.3 & 28 & 65 & $\mathrm{H}$ & $\mathrm{H}$ & $\mathrm{O}$ & $\mathrm{A}$ & $\begin{array}{l}4,28,36,51,54 \\
61,72,73,76\end{array}$ \\
\hline $\begin{array}{l}\text { Bald Eagle } \\
\quad \text { Haliaeetus leucocephalus }\end{array}$ & is 2 & 5669 & 2.5 & 264.1 & 35 & 74 & $\mathrm{~L}$ & $\mathrm{H}$ & $\mathrm{O}$ & A & $\begin{array}{l}2,8,21,31,38 \\
40,42,43\end{array}$ \\
\hline $\begin{array}{l}\text { Golden Eagle } \\
\text { Aquila chrysaetos }\end{array}$ & 2 & 4913 & 2.0 & 249.0 & 42 & 65 & $\mathrm{~L}$ & $\mathbf{H}$ & $\mathrm{O}$ & I & $6,11,37,47$ \\
\hline
\end{tabular}


Table 1. Continued.

\begin{tabular}{|c|c|c|c|c|c|c|c|c|c|c|c|}
\hline \multirow[b]{2}{*}{ SPECIES } & \multirow{2}{*}{$\begin{array}{c}\text { NEST } \\
\text { DEFENSE } \\
\text { CATEGORY }\end{array}$} & \multirow{2}{*}{$\begin{array}{c}\text { MEAN } \\
\text { FEMALF } \\
\text { MASS (g) }\end{array}$} & \multirow{2}{*}{$\begin{array}{l}\text { Avg. Clutch } \\
\text { Size }\end{array}$} & \multirow{2}{*}{$\begin{array}{c}\text { MEAN } \\
\text { ClutCh } \\
\text { Volume } \\
(\mathrm{ml})\end{array}$} & \multirow{2}{*}{$\begin{array}{l}\text { MEAN } \\
\text { INCUB. } \\
\text { PERIOD } \\
\text { (days) }\end{array}$} & \multirow{2}{*}{$\begin{array}{c}\text { MEAN } \\
\text { NESTLING } \\
\text { PERIOD } \\
\text { (days) }\end{array}$} & \multicolumn{2}{|c|}{ REPRODUCTIVE EFFORT } & \multirow{2}{*}{$\begin{array}{l}\text { Nesting } \\
\text { Habitat }\end{array}$} & \multirow{2}{*}{$\begin{array}{c}\text { NEST SITE } \\
\text { ACCESSIBILITY }\end{array}$} & \multirow[b]{2}{*}{ SOURCES } \\
\hline & & & & & & & EARLY & LATE & & & \\
\hline $\begin{array}{l}\text { Crested Caracara } \\
\text { Caracara cheriway }\end{array}$ & 2 & 1219 & 2.5 & 167.9 & 30 & 56 & $\mathrm{~L}$ & $\mathrm{H}$ & o & $\bar{A}$ & $19,28,44$ \\
\hline $\begin{array}{c}\text { American Kestrel } \\
\text { Falco sparverius }\end{array}$ & 4 & 139 & 4.8 & 66.0 & 29 & 30 & $H$ & $\mathrm{H}$ & o & I & $\begin{array}{l}27,47,58,60, \\
69,74\end{array}$ \\
\hline $\begin{array}{l}\text { Merlin } \\
\quad \text { Falco columbarius }\end{array}$ & 4 & 218 & 4.2 & 82.6 & 30 & 28 & L & $\mathbf{H}$ & o & A & $\begin{array}{l}26,28,34,64, \\
70,72,73\end{array}$ \\
\hline $\begin{array}{l}\text { Prairie Falcon } \\
\text { Falco mexicanus }\end{array}$ & 4 & 863 & 5.0 & 211.2 & 30 & 40 & $\mathrm{H}$ & $\mathrm{L}$ & 0 & I & $20,28,63,67$ \\
\hline $\begin{array}{l}\text { Peregrine Falcon } \\
\text { Falco peregrinus }\end{array}$ & 4 & 950 & 3.5 & 153.0 & 38 & 40 & L & $\mathrm{L}$ & $\mathrm{O}$ & I & $\begin{array}{l}10,32,41,45, \\
71\end{array}$ \\
\hline $\begin{array}{l}\text { Gyrfalcon } \\
\text { Falco rusticolus }\end{array}$ & 4 & 1747 & 3.7 & 224.1 & 34 & 77 & $\mathrm{H}$ & $\mathrm{H}$ & $\mathrm{O}$ & I & $10,12,62$ \\
\hline
\end{tabular}

SOURCES:

(1) Andersen 1990; (2) Anthony and Isaacs 1989; (3) Armstrong and Euler 1983; (4) Bechard and Schmutz 1995; (5) Bednarz 1995; (6) Bent 1937; (7) Boal 2001; (8) Buehler 2000; (9) Burns 1911; (10) Cade 1960; (11) Camenzind 1969; (12) Clum and Cade 1994; (13) Collier 1996; (14) Cottrell 1982; (15) Craig et al. 1982; (16) Crocoll 1994; (17) Davis 1996; (18) Dawson and Mannan 1991; (19) Dickinson 1995; (20) Didonato 1992; (21) Dykstra 1992; (22) England et al. 1997. (23) Farquhar 1992; (24) Farquhar 1993; (25) Fitch et al. 1946; (26) Fox and Donald 1980; (27) Gard et al. 1989; (28) Glinski 1998; (29) Goodrich et al. 1996; (30) Grubb 1976; (31) Grubb and Shields 1977; (32) Hays 1987; (33) Henny et al. 1973; (34) James 1988; (35) Jamieson and Seymour 1983; (36) Knight et al. 1989; (37) Kochert et al. 2002; (38) Kralovec et al. 1992; (39) MacWhirter and Bildstein 1996; (40) Mahaffy and Frenzel 1987; (41) Marks 1992; (42) Mathisen 1983; (43) McKelvey 1979; (44) Morrison 1996; (45) Newton 1979; (46) O'Neill and Askins 1998; (47) Palmer 1988; (48) Poole 1983; (49) Poole 1989; (50) Poole et al. 2002; (51) Powers 1981; (52) Powers et al. 1984; (53) Preston and Beane 1993; (54) Ramakka and Woyewodzic 1993; (55) Roche 1996; (56) Rosenfield and Bielefeldt 199I; (57) Rosenfield and Bielefeldt 1993; (58) Saenger 1984; (59) Schroeder and Melquist 1975; (60) Smallwood and Bird 2002; (61) Snow 1974a; (62) Snow 1974b; (63) Snow 1974c; (64) Sodhi et al. 1993; (65) Speiser and Bosakowski 1991; (66) Squires and Reynolds 1997; (67) Steenhof 1998; (68) Stevenson and Meizen 1946; (69) Toland 1984; (70) Trimble 1975; (71) White et al. 2002; (72) Wiklund 1990a; (73) Wiklund 1990b; (74) Wilmers 1983; (75) Woffinden and Mosher 1979; (76) Zelenak and Rotella 1997. 
Nesting Habitat and Nest Accessibility. Three of four raptor species nesting in closed cover types exhibited very aggressive nest defense; at the genus level this proportion rises to $100 \%$ (Table 1). For species nesting in open cover types $(N=15)$, we recorded four, six, and five species having passive response, somewhat aggressive, and very aggressive nest defense, respectively (Table 1 ). Examination of this group at the genus level $(N=6$ genera), however, indicated that $86 \%$ had only passive response or somewhat aggressive nest defense, and only raptors in the genus Falco exhibited very aggressive nest defense (Table 1). Interestingly, within the genus Falco all species except for the Merlin, have inaccessible nests. Golden Eagles, which also nest in open cover types and have inaccessible nests, showed little nest defense (Table 1). More than $80 \%$ of species with accessible nests $(N=14)$ showed somewhat aggressive or very aggressive nest defense; however, at the genus level, $50 \%$ of genera (three of six genera) had only passive response nest defense (Table 1).

Phylogeny. When we mapped nest defense for raptors in our dataset on available phylogenies (Griffiths 1999, Riesing et al. 2003), we found that except for Merlins (Fig. 1a), raptors in the genus Falco exhibit very aggressive nest defense, and all have inaccessible nests. Another exception in Falconidae was the relatively large-bodied Crested Caracara (Fig. 1a), a tree nester in the subfamily Caracarinae (Griffiths 1999) that exhibits little nest defense. Northern Goshawks (Accipiter gentilis) and Cooper's Hawks (in the outgroup Accipiter, Griffiths 1999), which have open, accessible nests and nest in closed cover types exhibit very aggressive nest defense. These two species also have high reproductive effort early in the nesting period. The relatively smaller-bodied Red-shouldered Hawk (Buteo lineatus) had very aggressive nest defense, and the White-tailed Hawk had passive response nest defense, while other Buteos in our dataset had somewhat aggressive nest defense (Fig. 1b). Redshouldered Hawks are one of only two Buteo species that have high reproductive effort throughout the nesting period, whereas the relatively larger-bodied White-tailed Hawk has low reproductive effort early in the nesting period (Fig. 1b, Table 1).

Predator Type. Accounts of raptor nest defense for which the potential predator could be identified suggest differences in response to different predator types (Fig. 2). There were more accounts of somewhat aggressive or very aggressive defense behaviors (dive/chase and attack) against both diurnal and nocturnal avian predators $(N=61$ accounts and $N=10$ accounts, respectively), but more accounts noting less aggressive behaviors (call/circle) or no defense against potential human predators ( $N=37$ accounts). There were similar proportions of accounts in each defense category exhibited by raptors when defending against nonhuman mammalian predators, although there were only eight of these accounts.

\section{DISCUSSION}

We attempted to describe patterns in nest defense for a variety of diurnal North American raptors and to identify factors that may influence the types and expression of these behaviors. Our results suggest, as for many other birds, that a variety of factors affect nest defense of raptors, yet assessment of their relative influence is likely confounded by interactions among them. For example, any influence of reproductive effort on nest defense is likely complicated by body size. Relationships between body size and antipredator strategies are well documented among birds (Andersson and Norberg 1981, Wiklund and Stigh 1983) and across taxonomic groups (Larsen et al. 1996); typically larger species exhibit more aggressive nest defense. In our study, species that exhibit the highest levels of nest defense (those in the genus Falco, the two accipiters, and the Redshouldered Hawk), are small-bodied relative to other species in our sample and are the species best adapted for fast, highly maneuverable flight. These characteristics may afford them reduced risk of injury from a potential nest predator, suggesting the hypothesis that nest defense is influenced by flying ability.

Overall, the larger raptors showed less aggressive nest defense. They are not fast flyers and their size may deter predators before an attack occurs; thus, aggressive nest defense may not be as necessary to deter predators (Andersson and Norberg 1981, Wiklund and Stigh 1983). However, in contrast to this pattern, the Ferruginous Hawk (Buteo regalis) exhibits somewhat aggressive nest defense. If young of this species have particularly high reproductive value (high reproductive effort throughout the nesting period; Table 1), and the probability of nest loss to a predator is high (this hawk typically nests in open cover types on or close to the ground), parents are expected to show more aggressive nest defense (i.e., the Reproductive Value-Stimulus Value hypothesis; Patterson et al. 


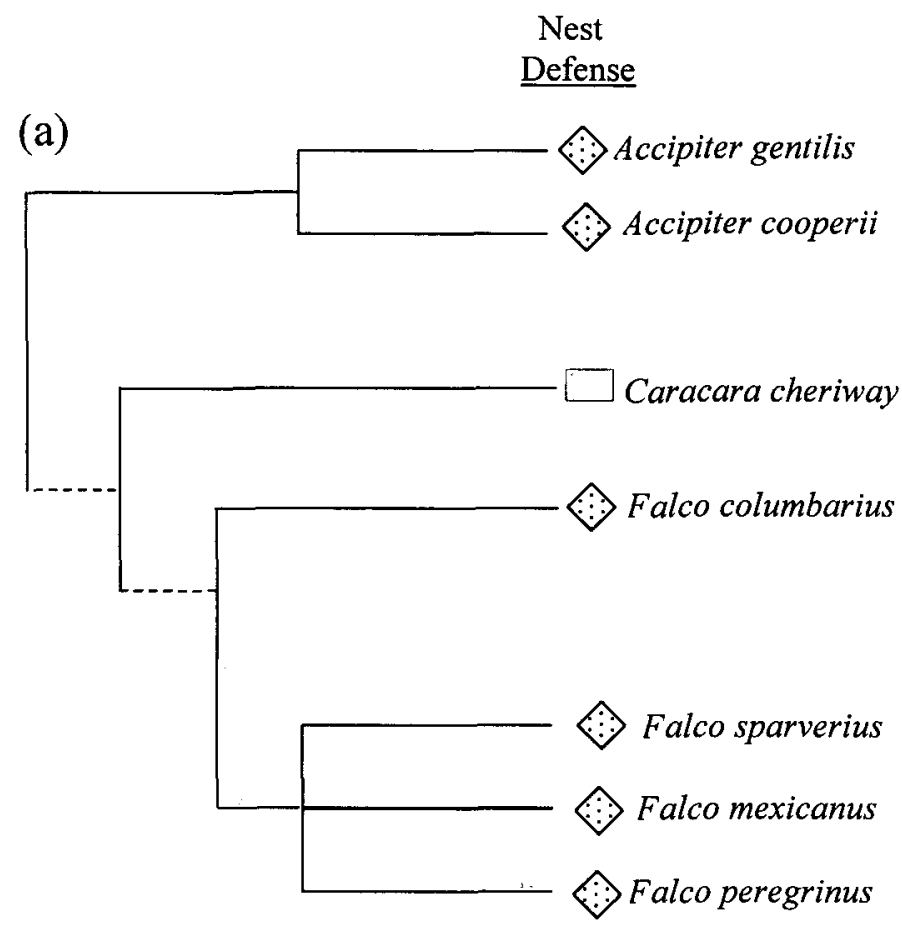

$\begin{array}{ll}\text { Nesting } & \text { Nest } \\ \text { Cover Type } & \text { Accessibility }\end{array}$
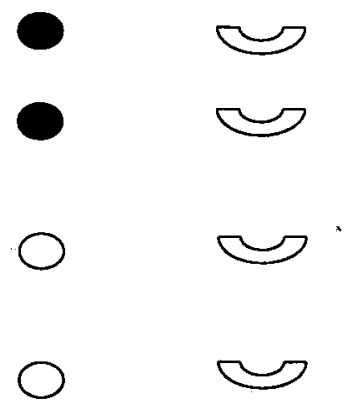

(b)
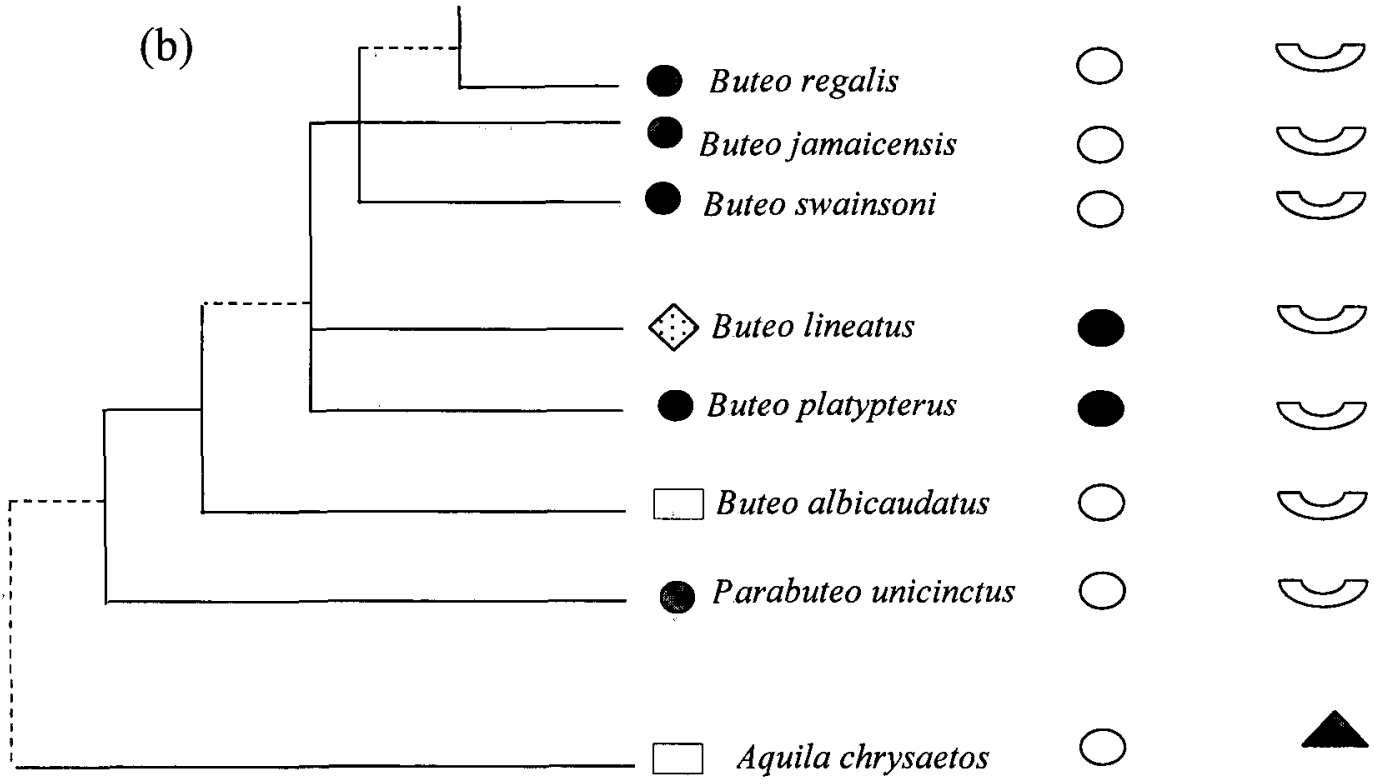

Figure 1. Nest defense behavior, nesting cover type, and nest type of 15 diurnal raptors mapped onto schematic phylogenies adapted from (a) Griffiths (1999) and (b) Riesing et al. (2003). Phylogenetic information was not available for Osprey, Bald Eagle, Gyrfalcon, and Northern Harrier. Nest defense behavior: $\uparrow=$ very aggressive, $\bigcirc=$ somewhat aggressive, $\square$ = passive response. Nesting cover type: $=$ closed cover type, $O=$ open cover type. Nest type: $\Delta=$ cliffs or cavities (inaccessible), $\smile=$ tree or ground nest (accessible). Line lengths are not to scale and dashed lines indicate levels or connections that are not shown. 


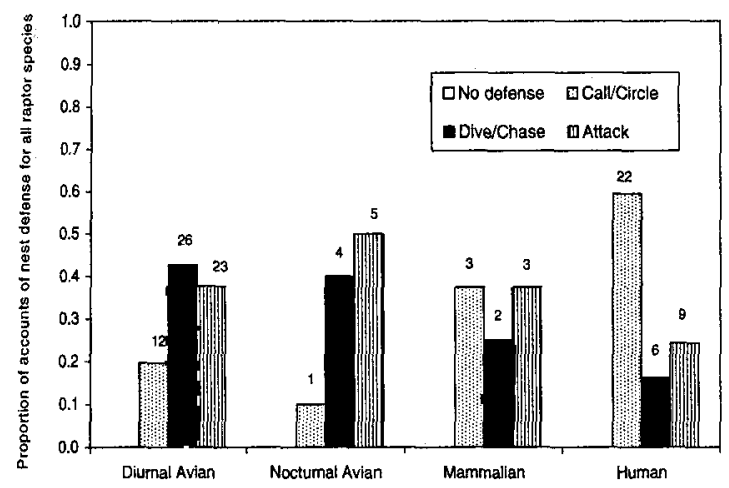

Figure 2. Responses by raptors to different predator types, $N=19$ species, 116 accounts. Numbers above the bars indicate number of accounts within each nest defense category.

1980) because potential risk to the parents may be offset by increased offspring security (Andersson et al. 1980). Similarly, Swainson's Hawks (Buteo swainsoni) nest in sparse shrubs or trees occurring in open cover types, nest sites that may be limiting as they are frequently subject to takeover by other species such as Red-tailed Hawks (Buteo jamaicensis), Common Ravens (Corvus corax), and crows (Cottrell 1982, England et al. 1997). Competition for limited, safe nest sites may lead to more aggressive nest defense by adult Swainson's Hawks.

Interactions between nest type and nesting habitat probably also influence nest defense. We originally predicted that raptors nesting in open cover types would not exhibit aggressive nest defense because such behaviors may be overtly conspicuous to visually-oriented predators leading to high rates of nest discovery and loss (Carillo and Aparicio 2001, Bures and Pavel 2003). Our results did not support this prediction overall, but exceptions were noted. For example, in open grasslands in Florida, Crested Caracaras show little nest defense ( $\mathrm{J}$. Morrison unpubl. data). Crows, common nest predators in that landscape operate in groups; thus, efforts by a pair of caracaras to defend their nest may not be worth the potential risk to themselves from these aggressive social predators.

The raptors in our dataset differed in their responses to different predator types, which is similar to findings for other avian species. Typically, the intensity of nest defense and tendencies toward risk vary by predator type and length of time the birds had been exposed to the predator (Knight 1984, Gottfried et al. 1985, Brunton 1990, Ferrer et al. 1990, Halupka 1999). Our finding that raptors exhibit less aggressive nest defense against potential human predators supports our original prediction and results of other studies. Knight et al. (1989) found that call and dive rates for Red-tailed Hawks were highest in areas more recently settled by humans and lowest in sites settled the longest, suggesting habituation to humans. Long-eared Owls (Asio otus) experiencing higher levels of human persecution show less aggressive nest defense than owls breeding in undisturbed areas perhaps because the former have become unwilling to take risks against human predators (Galeotti et al. 2000). Nesting birds worldwide probably perceive humans as a serious threat, but it is likely that this perception varies greatly with differences in human behavior. Where birds experience low levels of threat from humans, parents may exhibit high levels of nest defense (Knight et al. 1987, Ferrer et al. 1990). By contrast, where nesting birds are frequently shot or trapped, parental defense may be too costly. Thus, low levels of nest defense against humans may be the most frequent strategy in areas of intense human pressures.

Study Limitations. While our investigations indicate some patterns in nest defense exhibited by diurnal North American raptors, our results may be influenced by erroneous classifications, the most likely sources of which are limitations with the literature and intraspecific variation in behaviors across a species' geographic range or even within a local area. We found few North American species that had been the subject of a study focused on nest defense, and sample size for our analyses was limited because of large variation in the number and types of accounts (description of the behavior, identification of the predator) per species. We even identified several diurnal North American raptors for which very limited or no information was available on nest defense. In most cases, our sample sizes were too small for rigorous statistical analysis; therefore, our pattern descriptions are preliminary and mainly suggest further hypotheses for testing.

Additionally, we found wide variation among studies and species in the ways in which nest defense behavior was reported. In most studies, reports of behavior patterns associated with nest defense were anecdotal and typically reported incidental to other observations; therefore, inter- 
pretation was difficult. The gender of the aggressor was rarely reported, yet for many avian species the role of males and females in defense differs considerably (Regelmann and Curio 1986, Breitwisch 1988), and the degree of defense behavior often depends on whether one or both parents are present near the nest (Regelmann and Curio 1983, Larsen et al. 1996). Similarly, the types and intensity of nest defense is correlated with the stage in the nesting period (Andersson et al. 1980, Greig-Smith 1980, Biermann and Robertson 1981) and age of the parent (Pugesek 1983), and this information was rarely available for accounts of raptor nest defense.

Implications for Future Research. Avian nest defense has received much attention in the context of both life-history and parental-investment theory. An interesting finding that has emerged from these studies is that most variability in defense behavior remains unexplained. Our results suggest that more work is needed on the relative influence of the variety of factors (for example, mating system; see Malan and Jenkins 1996) that may influence raptor nest defense strategies before general patterns can be elucidated. The predictions developed in this study could be used as a prior predictions for future correlative and experimental studies. Such studies would benefit from standardized protocols that allow for collection of repeatable and less subjective behavioral data. We also encourage experimental approaches that test the effect of manipulated predation risk on defense strategies. Such studies for other avian species have incorporated presentations of mounted and live predators at nests (e.g., Patterson et al. 1980, Röell and Bossema 1982, Regelmann and Curio 1983) and evaluated responses to familiar versus novel predators (e.g., Knight and Temple 1986). Rigorous tests of hypotheses about relationships between nest defense and reproductive effort will require manipulation of effort via manipulations of clutch and brood size (e.g., Tolonen and Korpimäki 1995). Finally, understanding factors influencing raptor nest defense may be important from a conservation perspective. Birds may be exposed to new types and numbers of predators as ecological communities change in response to human activities. The effect these changes have on predation risk and the ability of species to defend nests successfully in these changing environments is mostly unknown (Koivula and Rönkä 1998).

\section{ACKNOWLEDGMENTS}

We thank B. Sandercock, G. Ritchison, K. MacLean, D. Hohler, R.L. Knight, J. Belthoff, and one anonymous reviewer for commenting on earlier versions of this manuscript. We also thank C. Griffiths and D. Blackburn for help with our explorations of associations between raptor phylogenies and nest defense behaviors, and $A$. Lueders, M. Howard and E. McClaren for help in designing the study.

\section{Literature Cited}

AlbRECHT, T. AND P. KLVANA. 2004. Nest crypsis, reproductive value of a clutch, and escape decisions in incubating female mallards Anas platyrhynchos. Ethology 110:603-613.

ANDERSEN, D.E. 1990. Nest-defense behavior of Red-tailed Hawks. Condor 92:991-997.

ANDERSSON, M. AND R. NORBERG. 1981. Evolution of reversed sexual size dimorphism and role partitioning among predatory birds, with a size scaling of flight performance. Biol. J. Linnean Soc. 15:105-130.

- C.G. WikLund AND H. RundGren. 1980. Parental defense of offspring: a model and an example. Anim. Behav. 28:536-542.

ANTHONY, R.G. AND F.B. ISAACS. 1989. Characteristics of Bald Eagle nest sites in Oregon. J. Wildl. Manage. 53:148-159.

Armstrong, E. AND D. Euler. 1983. Habitat usage of two woodland Buteo species in central Ontario. Can. Field Nat. 97:200-207.

BARASH, D.P. 1975. Evolutionary aspects of parental behavior: distraction behavior of the Alpine Accentor. Wilson Bull. 87:367-373.

BECHARD, M.J. AND J.K. SCHMUTZ. 1995. Ferruginous Hawk. In A. Poole and F. Gill [EDS.], The birds of North America, No. 172. The Academy of Natural Sciences, Philadelphia, PA and The American Ornithologists' Union, Washington, DC U.S.A.

Bednarz, J.C. 1995. Harris' Hawk. In A. Poole and F. Gill [EDs.], The birds of North America, No. 146. The Academy of Natural Sciences, Philadelphia, PA and The American Ornithologists' Union, Washington, DC U.S.A.

BENT, A.C. 1937. Life histories of North American birds of prey. U.S. Natl. Mus. Bull. 167.

BIERMANN, G.C. AND R.J. RoBERTSON. 1981. An increase in parental investment during the breeding season. Anim. Behav. 29:487-489.

BOAL, C.W. 2001. Agonistic behavior of Cooper's Hawks. J. Raptor Res. 35:253-256.

BREITWisCH, R. 1988. Sex differences in defence of eggs and nestlings by Northern Mockingbirds, Mimus polyglottos. Anim. Behav. 36:62-72.

BRUNTON, D.H. 1990. The effects of nesting stage, sex, and type of predator on parental defense by Killdeer (Charadrius vociferus): testing models of avian parental defense. Behav. Ecol. Sociobiol. 26:181-190. 
BueHLer, D.A. 2000. Bald Eagle. In A. Poole and F. Gill [EDS.], The birds of North America, No. 506. The Academy of Natural Sciences, Philadelphia, PA and The American Ornithologists' Union, Washington, DC U.S.A.

BuRes, S. AND V. PAVEL. 2003. Do birds behave in order to avoid disclosing their nest site? Bird Study 50:73-77.

BURNS, F.L. 1911. A monograph of the Broad-winged Hawk (Buteo platypterus). Wilson Bull. 23:139-320.

CADE, T.J. 1960. Ecology of Peregrine Falcon and Gyrfalcon populations in Alaska. Univ. CA Publ. Zool. 63:151290.

CAMEnzIND, F.J. 1969. Nesting ecology and behavior of Golden Eagle. Brigham Yoning Univ. Sci. Bull. Biol. Ser. 10:4-15.

Carillo, J. AND J.M. Aparicio. 2001. Nest defense behaviour of the Eurasian kestrel (Falco tinnunculus) against human predators. Ethology 107:865-875.

Clum, N.J. AND T.J. CADE. 1994. Gyrfalcon. In A. Poole and F. Gill [EDS.], The birds of North America, No. 114. The Academy of Natural Sciences, Philadelphia, PA and The American Ornithologists' Union, Washington, DC U.S.A.

COLLIER, J. 1996. The Cooper's Hawk (Accipiter cooperii). Wildl. Rehabil. Today, Fall, 14-16.

COTTRELL, M.J. 1982. Resource partitioning and reproductive success of three species of hawks (Buteo spp.) in an Oregon prairie. M.S. thesis, Oregon State Univ., Corvallis, OR U.S.A.

Craig, T.H., E.H. Craig, AND J.S. Marks. 1982. Aerial talongrappling in Northern Harriers. Condor 84:239.

Crocoll, S.T. 1994. Red-Shouldered Hawk. In A. Poole and F. Gill [EDs.], The birds of North America, No. 107. The Academy of Natural Sciences, Philadelphia, PA and The American Ornithologists' Union, Washington, DC U.S.A.

Curio, E., K. REgelmanN, AND U. ZimmermanN. 1985. Brood defence in the Great Tit (Parus major): the influence of life-history and habitat. Behav. Ecol. Sociobiol. 16:273-283.

DAVIs, W.E., JR. 1996. About the cover: Northern Goshawk. Bird Observ. 24:231-232.

Dawson, J.W. AND R.W. Mannan. 1991. The role of territoriality in the social organization of Harris' Hawks. Auk 108:661-672.

DiCKINSON, V.M. 1995. Red imported fire ant predation on Crested Caracara nestlings in south Texas. Wilson Bull. 107:761-762.

Didonato, J.E. 1992. Intraspecific nest defense by Prairie Falcons. J. Raptor Res. 26:40.

DykstRA, C. 1992. Fisher seen climbing Bald Eagle nesttree. Passenger Pigeon 54:237-238.

ENGLaNd, A.S., M.J. Bechard, AND C.S. Houston. 1997. Swainson's Hawk. In A. Poole and F. Gill [EDS.], The birds of North America, No. 265. The Academy of Natural Sciences, Philadelphia, PA and The American Ornithologists' Union, Washington, DC U.S.A.
FarQUhar, G.C. 1992. White-tailed Hawk. In A. Poole and F. Gill [EDS.], The birds of North America, No. 30. The Academy of Natural Sciences, Philadelphia, PA and The American Ornithologists' Union, Washington, DG U.S.A.

_. 1993. Individual and intersexual variation in alarm calls of the White-Tailed Hawk. Condor 95:234-239.

Ferrer, M., L. Garcia, ANd R. Cadenas. 1990. Long-term changes in nest defense intensity of the Spanish Imperial Eagle. Ardea 78:395-404.

FITCH, H.S., F. SwENSON, AND D.F. Tillotson. 1946. Behavior and food habits of the Red-tailed Hawk. Condor 48:205-257.

Fox, G.A. AND T. DONALD. 1980. Organochlorine pollutants, nest-defense behavior, and reproductive success in Merlins. Condor 82:81-84.

Freckleton, R.P. 2000. Phylogenetic tests of ecological and evolutionary hypotheses: checking for phylogenetic independence. Funct. Ecol. 14:129-134.

Galeotti, P., G. TAvecchia, AND A. Bonetti. 2000. Parental defense in Long-eared Owls Asio otus: effects of breeding stage, parent sex, and human persecution. $J$. Avian Biol. 31:431-440.

GARD, N.W., D.M. BIRD, R. DENSMORE, AND M. HAMEL. 1989. Responses of breeding American Kestrels to live and mounted Great Horned Owls. J. Raptor Res. 23:99-102.

GLINSKI, R.L. [ED.] 1998. The raptors of Arizona. The University of Arizona Press, Tucson, AZ U.S.A.

GoOdrich, L.J., S.C. Crocoll, AND S.E. SENNER. 1996. Broad-winged Hawk. In A. Poole and F. Gill [EDS.], The birds of North America, No. 218. The Academy of Natural Sciences, Philadelphia, PA and The American Ornithologists' Union, Washington, DC U.S.A.

GotTFried, B.M., K. ANdrews, AND M. HAUg. 1985. Breeding Robins and nest predators: effect of predator type and defense strategy on initial vocalization patterns. Wilson Bull. 97:183-190.

Grieg-Smith, P.W. 1980. Parental investment in nest defense by Stonechats (Saxicola torquata). Anim. Behav. 28: 604-619.

GRIFFThHS, C.S. 1999. Phylogeny of the Falconidae inferred from molecular and morphological data. Auk 116: 116-130.

-, G.F. Barrowclough, J.G. Groth, and L. Mertz. 2004. Phylogeny of the Falconidae (Aves): a comparison of the efficacy of morphological, mitochondrial, and nuclear data. Mol. Phyl. Evol. 32:101-109.

GrüBb, T.C., JR. 1976. Nesting Bald Eagles attack researcher. Auk 93:842-843.

_ an active Osprey nest. Auk 94:140.

GunNeSS, M.A. AND P.J. WEATHERHEAD. 2002. Variation in nest defense in ducks: methodological and biological insights. J. Avian Biol. 33:191-198.

HALUPKA, L. 1999. Nest defence in an altricial bird with uniparental care: the influence of offspring age, brood size, stage of the breeding season, and predator type. Omis Fenn. 76:97-105. 
Harvey, P.H. and M.D. Pagel. 1991. The comparative method in evolutionary biology. Oxford Univ. Press, Oxford, U.K.

Hays, L.L. 1987. Peregrine Falcon nest defense against a Golden Eagle. J. Raptor Res, 21:67.

Henny, C.J., F.C. Schmid, E.M. Martin, and L.L. Hood. 1973. Territorial behavior, pesticides, and the population ecology of Red-shouldered Hawks in central Maryland, 1943-1971. Ecology 54:545-554.

HoY, D.F. 1979. Practical methods of estimating volume and fresh weight of bird eggs. Auk 96:73-77.

Hudson, P.J. AND D. NewBorN. 1990. Brood defence in a precocial species: variations in the distraction displays of red grouse, Lagopus lagopus scoticus. Anim. Behav. 40:254-261.

James, P.C. 1988. Female Merlin kills American Crow in nest defense. Blue Jay 46:50.

JAMIESON, I.G. AND N.R. SEYMOUR. 1983. Inter- and intraspecific agonistic behavior of Ospreys (Pandion haliaetus) near their nests. Can.J. Zool. 61:2199-2202.

KNIGHT, R.L. 1984. Responses of nesting ravens to people in areas of different human densities. Condor 90: 193-200.

- D.E. Andersen, M.J. Bechard, And N.V. Marr. 1989. Geographic variation in nest-defense behaviour of the Red-tailed Hawk Buteo jamaicensis. Ibis 131:22-26.

— D.J. Grout, AND S.A. Temple. 1987. Nest defense behavior of the American Crow in urban and rural areas. Condor 89:175-177.

- AND S.A. TEMPLE. 1986. Methodological problems in studies of avian nest defence. Anim. Behav. 34:561-566.

Kochert, M., K. Steenhof, C. McIntyre, and E. Craig. 2002. Golden Eagle. In A. Poole and F. Gill [EDs.], The birds of North America, No. 684. The Academy of Natural Sciences, Philadelphia, PA and The American Ornithologists' Union, Washington, DC U.S.A.

KorvULA, K. AND A. RŌNKÄ. 1998. Habitat deterioration and efficiency of anti-predator strategy in a meadow-breeding wader, Temminck's Stint (Calidris temminckii). Oecologia 116:348-355.

Kralovec, „M.L., R.L. Knight, G.R. Craig, and R.G. MCLEAN. 1992. Nesting productivity, food habits, and nest sites of Bald Eagles in Colorado and southeastern Wyoming. Southwest. Nat. 37:356-361.

Kruckenhauser, L., E. Haring, W. Pinkser, M.j. Riesing, H. Winkler, M. Wink, AND A. GaMAUf. 2004. Genetic vs. morphological differentiation of Old World buzzards (genus Buteo, Accipitridae). Norwegian Acad. Sci. Lett. 33:197-211.

KRŨGER, O. 2002. Interactions between common buzzard Buteo buteo and goshawk Accipiter gentilis: trade-offs revealed by a field experiment. Oikos 96:441-452.

LARSEN, T., T.X. SORDAHL, AND I. ByRKJEDAL. 1996. Factors related to aggressive nest protection behaviour: a comparative study of Holarctic waders. Biol. J. Linn. Soc. 58:409-439.
MacWhirter, R.B. AND K.L. Bildstein. 1996. Northern Harrier. In A. Poole and F. Gill [EDs.], The birds of North America, No. 210. The Academy of Natural Sciences, Philadelphia, PA and The American Ornithologists' Union, Washington, DC U.S.A.

MAHAFFY, M.S. AND L.D. FRENZEL. 1987. Elicited territorial responses of northern Bald Eagles near active nests. $J$. Wildl. Manage. 51:551-554.

Malan, G. AND A.R. JEnkins. 1996. Territory and nest defence in polyandrous pale chanting goshawks: do cobreeders help? S. Afr. J. Zool. 31:170-176.

MARKS, J.B. 1992. Rough-legged Hawk (Buteo lagopus). Passenger Pigeon 54:238.

MARTIN, T.E. 1995. Avian life history evolution in relation to nest sites, predation, and food. Ecol. Monogr. 65: 101-127.

MATHISEN, J.E. 1983. Nest site selection by Bald Eagles on the Chippewa National Forest. Pages 95-100 in D.M. Bird [ED.], Biology and management of Bald Eagles and Ospreys. Harpell Press, Ste. Anne de Bellevue, Quebec, Canada.

MCKelveY, R.W. 1979. A Black Bear in a Bald Eagle nest. Murrelet, Winter, 106-107.

Meilvang, D., A. Moksnes, ANd E. Roskaft. 1997. Nest predation, nesting characteristics and nest defence behaviour of fieldfares and redwings. J. Avian Biol. 28:331-337.

Montgomerie, R.D. AND P.J. Weatherhead. 1988. Risks and rewards of nest defense by parent birds. Quart. Rev. Biol. 63:167-187.

MoRrison, J.L. 1996. Crested Caracara. In A. Poole and F. Gill [EDS.], The birds of North America, No. 249. The Academy of Natural Sciences, Philadelphia, PA and The American Ornithologists' Union, Washington, DC U.S.A.

Newton, I. 1979. Population ecology of raptors. Buteo Books, Vermillion, SD U.S.A.

OlENDORF, R. AND S.K. ROBINSON. 2000. Effectiveness of nest defense in the Acadian Flycatcher Empidonax virescens. Ibis 142:365-371.

O'NeILl, D.C. AND R.A. Askins. 1998. Reproductive success of Ospreys at two sites in Connecticut. Conn. Warbler 18:120-132.

PALMER, R.S. [ED.] 1988. Handbook of North American birds. Vol. 5. Yale Univ. Press, New Haven, CT U.S.A.

Patterson, T.L., L. Petrinovich, AND D.K. James. 1980. Reproductive value and appropriateness of response to predators by White-crowned Sparrows. Behav. Ecol. Sociobiol. 7:227-231.

POole, A.F. 1983. Courtship feeding, clutch size, and egg size in Ospreys: a preliminary report. Pages 243-256 in D.M. Bird [ED.], Biology and management of Bald Eagles and Ospreys. Harpell Press, Ste. Anne de Bellevue, Quebec, Canada.

1989. Ospreys: a natural and unnatural history. Cambridge University Press, Cambridge, MA U.S.A. 
R.O. BIERREGard, AND M.S. MARTEL. 2002. Osprey. In A. Poole and F. Gill [EDS.], The birds of North America, No. 683. The Academy of Natural Sciences, Philadelphia, PA and The American Ornithologists' Union, Washington, DC U.S.A.

- AND F. GILL [EDS.] 2002. The birds of North America. The Academy of Natural Sciences, Philadelphia, PA and The American Ornithologists' Union, Washington, DC U.S.A.

POWERS, L.R. 1981. Nesting behavior of the Ferruginous Hawk (Buteo regalis). J. Raptor Res. 17:94-95.

, T.H. Craig, and J. Martin. 1984. Nest defense by Northern Harriers against the coyote in southwestern Idaho. J. Raptor Res. 18:78-79.

Preston, C.R. AND R.D. Beane. 1993. Red-tailed Hawk. In A. Poole and F. Gill [EDS.], The birds of North America, No. 52. The Academy of Natural Sciences, Philadelphia, PA and The American Ornithologists' Union, Washington, DC U.S.A.

PugESEK, B.H. 1983. The relationship between parental age and reproductive effort in the California Gull (Lamus californicus). Behav. Ecol. Sociobiol. 13:161-171.

RAMAKKA, J.M. AND R.T. WoyewodzIC. 1993. Nesting ecology of Ferruginous Hawk in northwestern New Mexico. J. Raptor Res. 27:97-101.

REDONDO, T. 1989. Avian nest defense: theoretical models and evidence. Behaviour 111:161-195.

RegelmanN, K. AND E. CuRIO. 1983. Determinants of brood defence in the Great Tit Pamus major. Behav. Ecol. Sociobiol. 13:131-145.

- AND - 1986. Why do Great Tit (Parus major) males defend their brood more than females do? Anim. Behav. 34:1206-1214.

RiesinG, M.J., L. Kruckenhauser, A. Gamauf, and E. HARING. 2003. Molecular phylogeny of the genus Buteo (Aves: Accipitridae) based on mitochondrial marker sequences. Mol. Phylogen. Evol. 27:328-342.

RocHE, J.P. 1996. The use of a rock by an Osprey in an agonistic encounter. J. Raptor Res. 30:42-43.

Róell, A. AND I. Bossema. 1982. A comparison of nest defense by Jackdaws, Rooks, Magpies, and Crows. Behav. Ecol. Sociobiol. 11:1-6.

RoSENFIELD, R.N. AND J. BielEFELDT. 1991. Reproductive investment and anti-predator behavior in Cooper's Hawks during the pre-laying period. J. Raptor Res. 25:113-115.

AND - 1993. Cooper's Hawk. In A. Poole and F. Gill [EDs.], The birds of North America, No. 75. The Academy of Natural Sciences, Philadelphia, PA and The American Ornithologists' Union, Washington, DC U.S.A.

SAEnger, P.G. 1984. Territorial dispute between female American Kestrels. J. Field Omithol. 55:387-388.

SCHROEDER, G.J. AND W.E. MELQUIST. 1975. Intraspecific agonistic behavior of Ospreys (Pandion haliaetus). Condor 77:99-100.
Smallwood, J.A. AND D.M. BIRD. 2002. American Kestrel. In A. Poole and F. Gill [EDS.], The birds of North America, No. 602. The Academy of Natural Sciences, Philadelphia, PA and The American Ornithologists' Union, Washington, DC U.S.A.

SNOw, C. 1974a. Ferruginous Hawk. Habitat management series for unique or endangered species, Report No. 13. Technical Note T-N-255. U.S. Department of Interior, Bureau of Land Management, Denver, CO U.S.A.

- 1974b. Gyrfalcon. Habitat management series for unique or endangered species, Report No. 9. Technical Note T-N-241. U.S. Department of Interior, Bureau of Land Management. Denver, CO U.S.A.

1974c. Prairie Falcon. Habitat management series for unique or endangered species, Report No. 8. Technical Note T-N-240. U.S. Department of Interior, Bureau of Land Management. Denver, CO U.S.A.

SODHI, N.S., L.W. Oliphant, P.C. JAMES, AND I.G. WARKENTIN. 1993. Merlin. In A. Poole and F. Gill [EDS.], The birds of North America, No. 44. The Academy of Natural Sciences, Philadelphia, PA and The American Ornithologists' Union, Washington, DC U.S.A.

SPEISER, R. AND T. BosakowSKI. 1991. Nesting phenology, site fidelity, and defense behavior of Northern Goshawks in New York and New Jersey. J. Raptor Res. 25:132-135.

SQuiRES, J.R. AND R.T. REYNOLDS. 1997. Northern Goshawk. In A. Poole and F. Gill [EDs.], The birds of North America, No. 298. The Academy of Natural Sciences, Philadelphia, PA and The American Ornithologists' Union, Washington, DC U.S.A.

Steenhof, K. 1998. Prairie Falcon. In A. Poole and F. Gill [EDS.], The birds of North America, No. 346. The Academy of Natural Sciences, Philadelphia, PA and The American Ornithologists' Union, Washington, DC U.S.A.

Stevenson, J.O. AND L.H. Meitzen. 1946. Behavior and food habits of Sennett's White-tailed Hawk in Texas. Wilson Bull. 58:198-205.

TOLAND, B. 1984. Attacks on a human by a nesting American Kestrel. J. Field Ornithol. 55:386-387.

TOlONEN, P. AND E. KORPIMĀKI. 1995. Parental effort of kestrels (Falco tinnunculus) in nest defense: effects of laying time, brood size, and varying survival prospects of offspring. Behav. Ecol. 6:435-441.

TrImble, S.A. 1975. Merlin. Habitat management series for unique or endangered species, Report No. 15. Technical Note T-N-271. U.S. Department of Interior, Bureau of Land Management. Denver, CO U.S.A.

VILLAGE, A. 1983. The role of nest-site availability and territorial behavior in limiting the breeding density of Kestrels. J. Anim. Ecol. 52:635-645.

WEsolowski, T. AND L. Tomialojć. 2005. Nest sites, nest depredation, and productivity of avian broods in a primeval temperate forest: do the generalizations hold? J. Avian Biol. 36:361-367. 
White, C.M., N.J. Clum, T.J. CADE, AND W.G. Hunt. 2002. Peregrine Falcon. In A. Poole and F. Gill [EDs.], The birds of North America, No. 660. The Academy of Natural Sciences, Philadelphia, PA and The American Ornithologists' Union, Washington, DC U.S.A.

WIKLUND, C.G. 1990a. The adaptive significance of nest defense by Merlin, Falco columbarius, males. Anim. Behav. 40:244-253.

. 1990b. Offspring protection by Merlin Falco columbarius females; the importance of brood size and expected offspring survival for defense of young. Behav. Ecol. Sociobiol. 26:217-223.

AND J. STIGH. 1983. Nest defence and evolution of reversed sexual size dimorphism in Snowy Owls Nyctea scandiaca. Ormis Scand. 14:58-62.
WILMERS, T.J. 1983. Four Kestrels defend nest box containing eyasses. J. Raptor Res. 17:94-95.

WiNkLER, D.W. 1992. Causes and consequences of variation in parental defense behavior by Tree Swallows. Condor 94:502-520.

WOFFINDEN, N.D. AND J.A. MOSHER. 1979. Ground nesting and aggressive behavior by the Swainson's Hawk (Buteo swainsoni). Great Basin Nat. 39:253-254.

ZelenAK, J.R. AND J.J. Rotella. 1997. Nest success and productivity of Ferruginous Hawks in northern Montana. Can. J. Zool. 75:1035-1041.

Received 6 August 2002; accepted 26 March 2006 Associate Editor: James R. Belthoff 